\title{
自由意志信念が社会的相互作用場面での攻撃行動に与える効果 一運命的決定論信念に着目して一
}

\author{
福本都（東京大学 文学部, miyako-fukumoto821@g.ecc.u-tokyo.ac.jp） \\ 苫米地飛（東京大学 文学部, tob-tomabechi973@g.ecc.u-tokyo.ac.jp） \\ 橋本 剛明（東京大学大学院人文社会系研究科, hshmt@1.u-tokyo.ac.jp） \\ 唐沢かおり（東京大学大学院人文社会系研究科, karasawa@1.u-tokyo.ac.jp）
}

\author{
The effect of free will belief on aggression in social interactive situations \\ Miyako Fukumoto (Faculty of Letters, The University of Tokyo, Japan) \\ Tobu Tomabechi (Faculty of Letters, The University of Tokyo, Japan) \\ Takaaki Hashimoto (Graduate School of Humanities and Sociology, The University of Tokyo, Japan) \\ Kaori Karasawa (Graduate School of Humanities and Sociology, The University of Tokyo, Japan)
}

\begin{abstract}
Existing research have investigated the effects of free will belief on aggressive behaviours. So far, studies have shown that when people's free will belief is denied, their motivation of self-control decreases, thereby increasing aggressive behaviours. An alternative and inconsistent account is that people who have strong belief in free will attributes the other party's attack to the actor's intention, which lead them to take revenge. Given that aggressions practically occur within a social interaction, the present study examined the relationship between free will belief and aggression in a social interactive situation. We hypothesized that people who have high free will belief will behave more aggressively when they are attacked by another individual. Based on a sample of 45 undergraduates, we measured free will beliefs and trait aggression as an individual-difference variable. We employed a modification of the Point Subtraction Aggression Paradigm in order to measure participants' aggressive behaviours. As a result, the effects of fatal determinism-a subscale of free will - were found significant. Specifically, when participants were unattacked by their interactive partner, those with low fatal determinism belief behaved less aggressively. Incurring no attack from the partner, participants may have experienced higher responsibility for taking aggressive actions themselves. Under such circumstance, having a low fatal determinism belief, and thus regarding their behaviour as undetermined by nature, may have further increased their sense of responsibility, consequently decreasing aggression. In contrast, when participants were attacked by their partner, aggressive behaviours increased on the whole relative to the non-attacked condition; receiving an attack may have simply provoked participants' motivation to revenge. This study highly suggests the relationship between fatal determinism belief and aggression in social interaction situations, offering a ground for future investigations including parameters to further explain the relationship.
\end{abstract}

\section{Key words}

free will, fatal determinism, aggression, social interaction, responsibility

\section{1. 目的}

自由意志信念と社会的判断や行動との関係に関する研 究が着目してきたことの一つは、攻撃行動への影響であ る。このテーマに関する最も初期の研究である Baumeister, Masicampo \& DeWall（2009）は、自由意志信念が低いほ ど攻撃行動が増えることを示し、その理由について、自 由意志の存在の否定によって自己制御動機が低くなるか らであるという考察を提出した。攻撃行動の増加という 知見、また自己制御動機の低下にその原因を求める議論 は、自由意志信念の低下が道徳的行動を抑制するという 研究結果（Vohs \& Schooler, 2008）とも整合的であり、一 定の妥当性があると考えられる。しかし、Baumeister et al. (2009) の研究では無実な他者に対する攻撃行動を測定し
たのに対し、実際の攻撃行動は社会的な相互作用場面で 行われる。また、一般に攻撃行動は望ましくないとされ ているため、自発的な攻撃行動は行われにくいが、相手 の攻撃に対する報復であれば、正当性が認められやすく 発動もしやすい。したがって、攻撃行動に関する影響に 関して外的妥当性の高い議論を行うためには、社会的相 互作用を模した場面で、報復としての攻撃に着目した実 験的検討が重要となる。

この点について、松本・櫻井・渡辺・唐沢（2014）は、 自由意志信念と社会的相互作用場面における攻撃行動と の関係を検討する実験研究を行った。具体的には、他者 とのゲームという相互作用場面を用いて、攻撃行動特性 の個人差と自由意志信念が、ゲーム相手に与える報復と しての攻撃度に及ぼす影響が検討された。結果として、 もともと個人の持つ攻撃特性が高い参加者のうち、自由 意志信念を肯定する文章を読んだ参加者（自由意志条件） は攻撃に対する報復行動が強くなり、自由意志と無関係 
な文章を読んだ参加者（統制条件）や自由意志の存在を 否定する文章を読んだ参加者（決定論条件）は攻撃行動 が強くならないということが示された。一方、攻撃特性 の低い参加者に関しては、統制条件での夕攻撃行動が生 じ、自由意志条件と決定論条件では攻撃行動の表出はほ とんじなかった。

このような結果は、一般的に自由意志信念が自己制御 を高め、道徳的行動を促進したり攻撃行動を抑制したり するという知見とは異なり、自由意志肯定条件のみに着 目すれば、自由意志信念が攻撃行動を促進することを示 唆している。これは、自由意志信念が肯定されると、相 手の攻撃行動が当人の意志に基づくと判断され、報復へ と繋がったと解釈できるだろう。

一方、この結果は、個人差としての攻撃特性が高い 参加者に限られている。この点について松本ら（2014） は、個人差測定に用いた日本語版 Buss-Perry Aggression Questionnaire（以下 BAQ と呼ぶ; 安藤・曽我・山崎・島 井・嶋田・宇津木・大芦・坂井，1999）が「相手の攻撃 や侵害に対する攻撃の行いやすさを測定している」ため に、BAQ で得点が低い参加者はどのような状況でも滅多 に攻撃行動が生じないからだ、と考察している。しかし、 BAQ は「身体的攻撃」「言語的攻撃」「短気」「敵意」の 4 つの下位尺度から成り、中でも「短気」や「敵意」は 「攻撃の行いやすさ」を測定しているとは言えないため、 BAQ が「相手の攻撃や侵害に対する攻撃の行いやすさを 測定している」と断言することはできない。また、統制 条件では BAQ 得点が低い参加者でも攻撃行動が生じてい るため、このような説明が適合するとは言いがたい。さ らに、Schooler, Nadelhoffer, Nahmias \& Vohs（2014）によ れば、自由意志は頑健で、プライミングの操作によって 変えることが難しい信念であるため、松本ら（2014）のとっ た方法では操作が成功しなかった可能性があると考えら れる。

以上を踏まえて本研究では、松本ら（2014）の用いた 手法に改変を加えたうえで、自由意志信念が高いと、報 復としての攻撃行動が増加するという仮説の妥当性の再 検討を行うことを目的とする。また、松本ら（2014）の 研究ではなされなかった、攻撃的な他者と非攻撃的な他 者に対する反応の比較も行った。

再検討に当たって、実験の方法として改善した点は以 下のとおりである。まず、プライミングによる自由意志 信念の操作が難しいことを考え、参加者の自由意志信念 を個人差として測定した。攻撃行動の測定についても次 のような方法の改善を行った。松本ら（2014）は、攻撃 行動の測定の前にストループ課題の不一致試行を行わせ て攻撃行動の表出を促進したが、本研究では、社会的相 互作用場面の中でより自然に表出する攻撃行動につい て検討するため、ストループ課題は行わせなかった。ま た、松本ら（2014）は、反応時間競争パラダイム（Taylor, 1967）を用いた攻撃交換課題を攻撃行動の測定に利用し ていた。この課題では、参加者が架空の対戦相手と反応 時間を競い、その勝敗によってノイズを数十回与えあう
ことによって攻撃交換を行う。しかしこの方法では、初 めにノイズを聞かせることやゲームでの勝敗が攻撃行動 に影響を与える可能性がある。そこで、本研究では Point Subtraction Aggression Paradigm（以下 PSAP 課題と呼ぶ; Cherek, Moeller, Schnapp \& Dougherty, 1997; Carré, Gilchrist, Morrissey \& McCormick, 2010）を一部改変したものを課 題として用いた。PSAP 課題は、他の参加者とペアになっ てそれぞれが自身の得点の最大化を目指すゲームであり、 自分の得点加算、相手の得点減算 (攻撃)、相手の攻撃人 の防御の 3 つの応のうちいずれかをキー押しにより選 択することによって行われるものである。なお、Cherek et al. (1997) とC Carré et al.（2010）の両研究において、 PSAP 課題で測定した攻撃行動と従属変数との関連が確認 されている。

本研究では、Cherek et al. (1997) の実験パラダイムを もとに、それに以下のような改変を加えた。彼らの実験 では、ゲームが始まると、参加者は $1 、 2 、 3$ のキーを押 すことで 3 つの行動をとることができた。1のキーを 100 回押すと 1 ポイントが自分の得点として加算され（得点）、 2 のキーを 10 回押すとペアの得点を 1 ポイント減らすこ とができ (攻撃)、3 のキーを 10 回押すと、ペアが 2 のキー で参加者自身の得点を減らすことを 250 秒間防御するこ とができた (防御)。ゲームの制限時間は 25 分間で、全 6 回のゲームが行われた。相手からの攻撃として 6〜12 分 に 1 回ポイントが減らされた。Carré et al. (2010) は、全 てのキーの規定回数を 50 回に統一し、相手からの攻撃が ない条件と、相手から減らしたポイントが自分のポイン トになる条件を追加して同様のゲームを行った。本実験 を実施するにあたってゲームを行ってみたところ、得点 キーを 100 回押すことに対する負担から攻撃や防御反応 を選んでしまう可能性を回避するため、効果発動に必要 なプッシュ回数を 1 キーは 50 回に減らした。なお、2、3キー は Cherek et al. (1997) と同様 10 回ずつとした。また、予 備実験より、25 分間キーを押し続けるゲームを 6 回繰り 返すことはかなり負担が大きいと判断し、ゲームの制限 時間を 5 分に、回数を 3 回に減らした。パイロットラン での内観報告にて、「忍耐できるぎりぎりの回数」という ものを得た。攻撃パターンは、Carré et al. (2010) と同様 攻撃あり条件と攻撃なし条件の 2 パターンであった。ま た、一切攻撃を受けずに自分のポイントを増やすという 行動を防ぐため、3キーで相手の攻撃を防御できる時間を、 1 キーを 50 回押しきるのが難しい程度の 10 秒間に設定し た（実際には、相手の攻撃を防御している 10 秒間に 1 を 50 回押すことを繰り返して全く攻撃を受けないことを可 能にした参加者もいた)。

\section{2. 方法}

\section{1 参加者}

実験参加者はウェブ上で募集した大学生 45 名（うち男 性 32 名、女性 13 名) で、年齢は 18 歳から 25 歳（平均 21.42、標準偏差 1.54）であった。 


\section{2 実験計画}

ゲームのペアの態度（攻撃的な態度をとる「攻撃条件」、 全く攻撃をしない「非攻撃条件」の参加者内 2 水準）と 課題の実施順序（攻撃条件から非攻撃条件の順でゲーム を実施する「攻撃先行」、攻撃条件から非攻撃条件の順で ゲームを実施する「非攻撃先行」の参加者間 2 水準) を 独立変数とする 2 要因混合計画であった。

\section{3 器具 - 装置}

実験中に行ったゲームと質問は、inquisit 4 を用いて作 成した。また、実験室内には $2 つ の$ 完全防音のブースの ほか、衝立を利用して、防音ではないブースが 2 つ設け られた。参加者には、一度に 4 名が実験に参加している と教示したが、実際には、一度に実験を行った参加者は 1 名、または 2 名であり、全員が防音ブース内で課題を行っ た。

\section{4 課題}

PSAP 課題を用いて攻撃行動を測定した（Cherek et al., 1997; Carré et al., 2010)。自らの得点をできるだけ増やす ことを目的とする課題であり、全試行を通じて獲得した 合計得点 1 ポイントにつき 5 円が、実験参加の基本報酬 である 700 円に上乗せされると教示した。

参加者には、「ゲームは、インターネットを通じて、実 験に同時に参加している残り 3 人の参加者からランダム に選ばれたペアと 2 人で行う。制限時間は 1 ゲーム当た り 5 分間で、ペアはゲームごとにランダムに選び直され、 同じペアと 2 度ゲームを行うことはない」と説明したが、 実際には、実験に同時に参加したのは 1 人か 2 人であ り、ゲームにおいて参加者がペアとなる相手の反応はコ ンピュータのプログラムにより制御されたものであった。 相手の反応は、頻繁に攻撃を仕掛ける「攻撃条件」と全 く攻撃を仕掛けない「非攻撃条件」の 2 パターンであった。 非攻撃条件は全く攻撃行動が起こらないように、攻撃条 件は、4.0 秒間から 9.0 秒間までを 0.5 秒刻みにした 11 通 りからランダムに選ばれた間隔で次の攻撃が起こるよう にプログラムした。これは、ペアが人間であるというこ とを疑わせない範囲で攻撃をされているという実感を参 加者に与えるために、2 キーを 10 回押して攻撃を発動さ せるのにかかる自然な時間である 4.0 秒間から、1 キーを 50 回押したのち 2 キーを 10 回押すのにかかる最も短い時 間である 9.0 秒間までに設定した。

ゲーム中、画面上部には獲得したポイント数が、画面 下部には各キーを押した回数が、画面右上には残り時間 が表示された（図 1)。ゲームが開始すると、参加者は、「1」 (50 回押すと自分の得点が 1 ポイント増える)、「2」(10 回押すとペアの得点が 1 ポイント減る)、「3」（10 回押す と 250 秒間は自分の得点が減らない）のうちいずれかを 選び、該当するキーを押すよう求められた。キーを押し 始めると、画面中央の $1 \sim 3$ のうち押したキーに当たる 数字が青くなり（図 2 ; 実際には画面左の「1」の文字が 青くなる)、画面下部にカウントされているキー押し回数

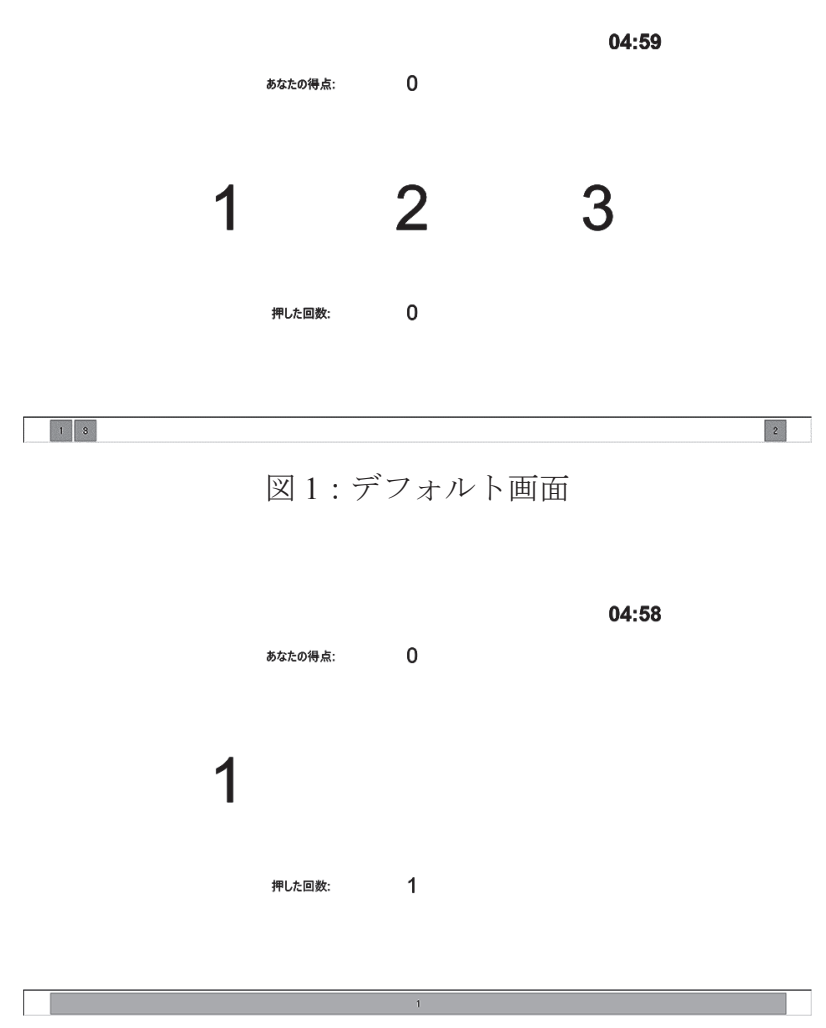

図 2:1キーを 1 度押した画面

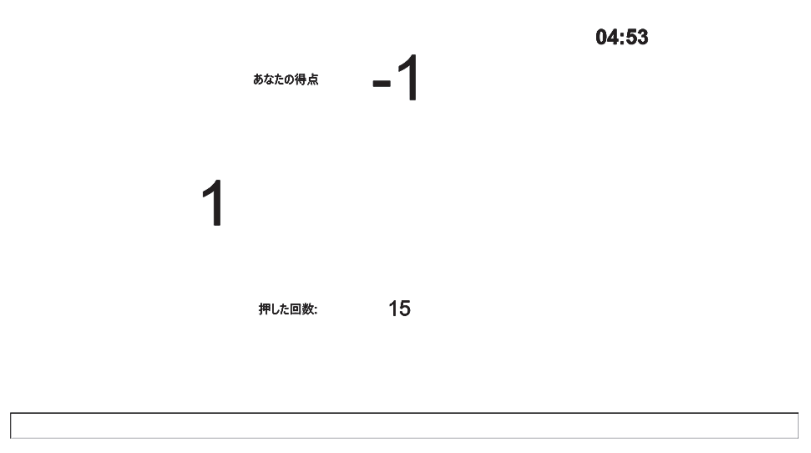

図 3 : 攻撃を受けた画面

が各キーの規定回数 (1キーなら 50 回、2,3キーなら 10 回) を満たすまでは他のキーを押しても無効となった。ペア からの攻撃があり、それを防御できなかった場合には、 画面上部の得点表示が赤く点滅して 1 ポイント減るよう になっていた（図 3 ; 実際には画面上部の「-1」の文字が 赤く、画面左の「1」の文字が青くなる)。各キーの規定 回数を押し終えると、再びキー選択画面となり、参加者は、 同様の手続きを 5 分間繰り返した。

\section{5 実験手続き}

実験に際しては、参加者が他の参加者と顔を合わせな いように、1 人ずつ実験室内の防音ブースに誘導した。 参加者には、常に 4 人が同時に参加している実験である と説明した。そのため、実際には参加者 1 人で実験を行 う際には、その参加者が 3 人目に実験室に案内された参 
加者であり、すでに 2 名の参加者が他のブースにいると 伝えた。また、参加者 2 人で行う際には初めに待ち合わ せた参加者には 3 人目に案内された参加者であると告げ、 次に待ち合わせた参加者には 4 人目であると告げた。参 加者がブース内に着席したのち、実験の概要の説明を行 うとともに、実験参加同意書への記入を求めた。

全員の参加同意書への記入を確認後、防音ブースの屝 を開放し、部屋全体に対して、実験全体の流れについて 口頭で説明した。その後、参加者に対して個別に事前質 問（後述の「質問項目」参照）への回答を求めた。全員 の回答終了を確認後、再び部屋全体に対して、ゲームの シナリオとルールについて教示した。この際、コンピュー タの画面上にもスライドを用意し、説明と同時に図や文 を提示することで理解漏れのないようにした。実験報酬 は、基本報酬の 700 円に 1 ポイントあたり 5 円を上乗せ する形で支払われ、上限は 1000 円であると説明した（実 験終了後にデブリーフィングを行い、満額の 1000 円をす ベての参加者に支払った)。また、相手と競争していると いう印象を与えてしまうことを避けるため、「対戦」「対 戦相手」といった言葉を使うのではなく「ペア」と表現 した。そして、各キーの説明の際は、キーに得点や攻撃 などの名称を付与することをせず、「1キー」「2キー」「3 キー」とし、社会的望ましさの影響を軽減した。

説明終了後、本試行に入る前に、コンピュータを相手 に制限時間 1 分間の練習試行を行った。なお、この時は、 参加者にペアがコンピュータであることを伝えた。その 後、ゲームに関して不明な点がないかを確認し、他の参 加者とのゲーム開始のタイミングを合わせ、本試行に移つ た。本試行のゲーム開始前の画面には、「ペアを決めてい ます」「ペアが決まりました」といった文を表示し、他の コンピュータと通信しているというシナリオに信憑性を 持たせた。各試行終了後、その時の感情状態が攻撃行動 に影響を与えていないことを確認するため、感情の測定 を行った。また、課題の条件を正確に認識しているかを 確認するため、ペアの攻撃性についての回答を求めた。 次の試行に移る前には必ず、ゲームに関して不明点がな いかを逐一確認した。2 回の本試行の後、統計的に必要な 事項（性別、年齢、所属大学・学部、学年）への回答を 求めた。最後に、研究の主旨に関してより詳しく説明し た上で丁寧にデブリーフィングを行い、内観を記録して、 実験を終了した。

\section{6 質問項目}

質問項目は、各問の中でランダムな順番で画面上に表 示された。課題の前に尋ねた「事前質問」では、独立変 数として自由意志、攻撃特性、統制変数として自己制御、 公正世界信念を「1. 全くそう思わない」〜「7. とてもそ う思う」の7 件法で測定した。松本ら（2014）の研究と 同様、自由意志は渡辺ら（2014）の日本語版 FAD+17 項 目、攻撃特性は安藤ら（1999）の日本語版 BAQ24 項目、 自己制御は尾崎（2016）のセルフコントロール尺度短縮 版 13 項目を使用した。公正世界信念については、Lipkus
（1991）の Global belief in a just world 尺度の日本語版（白井， 2010）７項目を用いた。

実験後には、感情状態とペアの攻撃性の認知を、「1. 全 くそう思わない」〜「7. とてもそう思う」の7 件法で測 定した。感情状態については松本ら（2014）に倣い日本 語版 PANAS（佐藤・安田，2001）16 項目を使用した。ぺ アの攻撃性に関する認知は、「相手は、攻撃的な人だ」の 1 項目で測定した。

\section{3. 結果}

\section{1 予備分析}

\section{1 .1 独立変数}

まず、日本語版 BAQ の 24 項目、自己制御尺度 13 項目、 公正世界信念尺度 7 項目に関して、それぞれ信頼性係数 を確認した。Cronbach’s $\alpha$ は BAQで.881、自己制御で.773、 公正世界信念で.805 であった。各尺度の単純加算平均得 点を、攻撃特性得点 (BAQ)、自己制御得点 $(\mathrm{SC})$ 、公正 世界信念得点 (JW) として以降の分析に用いた。

次に、日本語版 $\mathrm{FAD}+$ の 17 項目に対して、想定される 4 つの下位尺度が成り立つか検証した。最尤法プロマック ス回転による因子分析結果より、予測不可能性、運命的 決定論、自由意志の 3 因子による解を採用し、これらで 高い因子負荷量を得た項目の単純加算平均得点を算出し たものを、予測不可能性得点 (UP; $\alpha=.716$ )、運命的決 定論得点 $(\mathrm{FD} ; \alpha=.809)$ 、自由意志得点 $(\mathrm{FW} ; \alpha=.801)$ として以降の分析に用いた（表 1)。4つ目の次元として 想定された科学的決定論（3項目）は、1 項目ずつに $3 つ$ の因子が高い因子負荷量を示し、単独の因子としての独 立性が認められなかった。Cronbach’s $\alpha$ は.546であり、 十分に高い内定整合性が得られなかった。そのため、以 降の分析からは除外した。

日本語版 PANAS の 16 項目に対しても、最尤法プロマッ クス回転の因子分析を行った結果、ポジティヴ感情とネ ガティヴ感情の 2 因子が同定されることを確認した。ペ ア態度条件ごとのそれぞれの信頼性係数はポジティヴ感 情尺度で.852、非攻撃条件のポジティヴ感情尺度で.855、 攻撃条件のネガティヴ感情尺度で.899、非攻撃条件のネ ガティヴ感情尺度で.832であった。各尺度の単純加算平 均得点を、攻撃条件のポジティヴ感情得点 $\left(\mathrm{PA}_{\mathrm{AP}}\right)$ 、非攻 撃条件のポジティヴ感情得点 $\left(\mathrm{PA}_{\mathrm{NP}}\right)$ 、攻撃条件のネガティ ヴ感情得点 $\left(\mathrm{NA}_{\mathrm{AP}}\right)$ 、非攻撃条件のネガティヴ感情得点 $\left(\mathrm{NA}_{\mathrm{NP}}\right)$ とした。課題内容が感情に与える影響を確認する ために分散分析を行った。感情ごとに、相手の反応を参 加者内要因、課題の順序を参加者間要因とした 2 要因に 加え、その交互作用の効果も確認した。ポジティヴ感情 においては、条件、順序、交互作用のいずれの効果も見 られなかった（条件 : $F(1,43)=0.785$, n.s.; 順序 : $F(1,43)$ $=1.65$, n.S. ; 交互作用 : $F(1,43)=0.192$, n.s. $)$ 。一方で、礻 ガティヴ感情においては、ペアの態度の効果のみ有意で あった（条件 : $F(1,43)=18.947, p=.000$; 順序 $: F(1,43)$ $=0.091$, n.s.; 交互作用 : $F(1,43)=0.081$, n.s. $)$ 。攻撃条件の ペアと課題を行った場合は $(M=2.966, S D=0.181)$ 、非攻 
表 1:FAD+の 17 項目における因子分析の結果

\begin{tabular}{|c|c|c|c|c|}
\hline 質問項目 & FW & FD & UP & 共通性 \\
\hline [1] 人々の未来は予測することができない & -.101 & -.086 & .720 & .564 \\
\hline $\begin{array}{l}\text { [2] サイコロを投げたりコインをはじくように、人生は予測でき } \\
\text { ないと思われる }\end{array}$ & .091 & .247 & .826 & .661 \\
\hline [3]この世界で何が生じるかは、誰も予測ができない & -.148 & -.169 & .197 & .093 \\
\hline [4] 人は予測不可能である & -.224 & .131 & .422 & .255 \\
\hline [5] 人生はほぼすべてがランダムなため、予測することが難しい & -.008 & -.008 & .700 & .492 \\
\hline [6]未来は運命によって既に決定されていると思う & -.008 & .963 & .025 & .924 \\
\hline [7] 全ての人には、運命によって未来図が用意されている & -.054 & .816 & -.171 & .764 \\
\hline $\begin{array}{l}\text { [8] どんなに努力しても、みずからの宿命を変えることはできな } \\
\text { い }\end{array}$ & .167 & .612 & .227 & .353 \\
\hline [9] 人々は自分の悪い行動について常に非がある & .782 & .118 & .084 & .575 \\
\hline $\begin{array}{l}\text { [10] 人々は自分がした誤った選択に対して、すべての責任を取 } \\
\text { らなければなな }\end{array}$ & .725 & -.105 & .002 & .574 \\
\hline [11] 意志の強さは身体的欲求にいつでも打ち勝つことができる & .607 & .075 & -.141 & .389 \\
\hline $\begin{array}{l}\text { [12] 犯罪者は自分がした悪いおこないに対して、全ての責任を } \\
\text { 負う }\end{array}$ & .790 & -.136 & -.022 & .696 \\
\hline [13] 人々は完全な自由意志を持っている & .413 & .030 & -.124 & .190 \\
\hline $\begin{array}{l}\text { [14] 人々は真に望めば、どんな障害でも乗り越えることができ } \\
\text { る }\end{array}$ & .510 & -.041 & .052 & .271 \\
\hline [15] 親の特性が子どもの特性を決めるだろう & -.157 & .305 & .126 & .147 \\
\hline [16] 幼少期の環境が、大人になったときの成功を左右する & -.106 & .396 & -.418 & .412 \\
\hline [17] 遺伝子が人の将来を決定する & .385 & .286 & -.036 & .184 \\
\hline 因子寄与 & 3.023 & 2.649 & 2.317 & \\
\hline \multirow{2}{*}{ 因子間相関 } & FW & -.241 & -.075 & \\
\hline & FD & & -.167 & \\
\hline
\end{tabular}

注 $: \mathrm{FW}=$ 自由意志 $、 \mathrm{FD}=$ 運命的決定論、 $\mathrm{UP}=$ 予測不可能性

撃条件のペアと行った場合よりも $(M=2.122, S D=0.125)$ 、 ネガティヴ感情が強く喚起されていた。しかし、ネガティ ヴ感情を統制しても、後述する攻撃頻度に関する重回帰 分析の結果は変わらなかったため、仮説検証上の問題は ないと考えられる。

\section{1 .2 従属変数}

参加者が課題の中で、キーを押した総回数の内、「攻撃」 のためのキーを押していた割合を、攻撃頻度とした。

\section{1 .3 操作チェック}

参加者が、課題の条件を正確に認識していたか確認す る操作チェックを行った。相手の攻撃性が感じられたか という質問（「相手は、攻撃的な人だ」）への回答（7 件法） について分散分析を行った。尺度の理論的中間值である 4 を挟み、攻撃条件の平均值は $5.33(S D=1.33)$ 、非攻撃条 件の平均值は $1.84 （ \mathrm{SD}=1.13 ）$ であり、対戦相手の態度 の操作による有意差が認められた $(F(1,43)=126.407, p=$ .000)。試行順序および交互作用の効果は認められなかっ た（順序: $F(1,43)=2.604$, n.s.; 交互作用 : $F(1,43)=.856$, n.s.)。この結果から、操作の意図通り、攻撃条件では非 攻撃条件に比べて、相手に対する高い攻撃性が知覚され
ていたことが確認された。

\section{2 攻撃行動}

攻撃条件と非攻撃条件のそれぞれにおいて、自由意志 信念が攻撃行動に与えた効果を検討した。条件ごとの攻 撃頻度を従属変数として、独立変数に、自由意志、運命 的決定論、予測不可能性の 3 変数と、さらにはそれらと 課題順序、および BAQ との交互作用項を投入した重回帰 分析を行った（表 2)。

攻撃条件では、自由意志、運命的決定論、予測不可能 性と、順序、攻撃特性と、自由意志、運命的決定論、予 測不可能性の 3 つそれぞれと順序、BAQ との交互作用を 投入して重回帰分析を行った。運命的決定論と順序の交 互作用（FD ×順序）について、攻撃先行では運命的決定 論の効果は見られなかったが、非攻撃先行では運命的決 定論への信念が強いほど攻撃頻度が少なくなる効果が見 られた（攻撃先行: $\beta=.000, p=.970$; 非攻撃先行: $\beta=-.769$, $p=.002$; 図 4)。

非攻撃条件では、自由意志、運命的決定論、予測不可 能性と、順序、攻撃特性と、自由意志、運命的決定論、 予測不可能性の 3 つそれぞれと順序、BAQ との交互作用 を投入して重回帰分析を行った。運命的決定論と順序の 
表 2 : 攻撃条件と非攻撃条件における攻撃頻度の重回帰分 析の結果

\begin{tabular}{|c|c|c|}
\hline & \multicolumn{2}{|c|}{ 攻撃頻度 } \\
\hline & 攻撃条件 & 非攻撃条件 \\
\hline FD & $-.379+$ & .087 \\
\hline UP & $-.287+$ & -.075 \\
\hline FW & -.108 & $.245+$ \\
\hline 順序 & -.222 & -.166 \\
\hline $\mathrm{FD} \times$ 順序 & $.389 *$ & $.611 * *$ \\
\hline $\mathrm{UP} \times$ 順序 & -.062 & -.051 \\
\hline FW $\times$ 順序 & .017 & -.021 \\
\hline BAQ & .163 & $.559 * *$ \\
\hline $\mathrm{FD} \times \mathrm{BAQ}$ & .300 & $.422 *$ \\
\hline $\mathrm{UP} \times \mathrm{BAQ}$ & .230 & -.187 \\
\hline $\mathrm{FW} \times \mathrm{BAQ}$ & $.352+$ & $.292+$ \\
\hline$R_{A d j .}^{2}$ & $.226 *$ & $.390 * *$ \\
\hline
\end{tabular}

注 $: \mathrm{FD}=$ 運命的決定論、 $\mathrm{UP}=$ 予測不可能性、 $\mathrm{FW}=$ 自由意志、 $\mathrm{BAQ}=$ 攻撃特性 $; p<.01,{ }^{*} p$ $<.05,{ }^{+} p<.10$

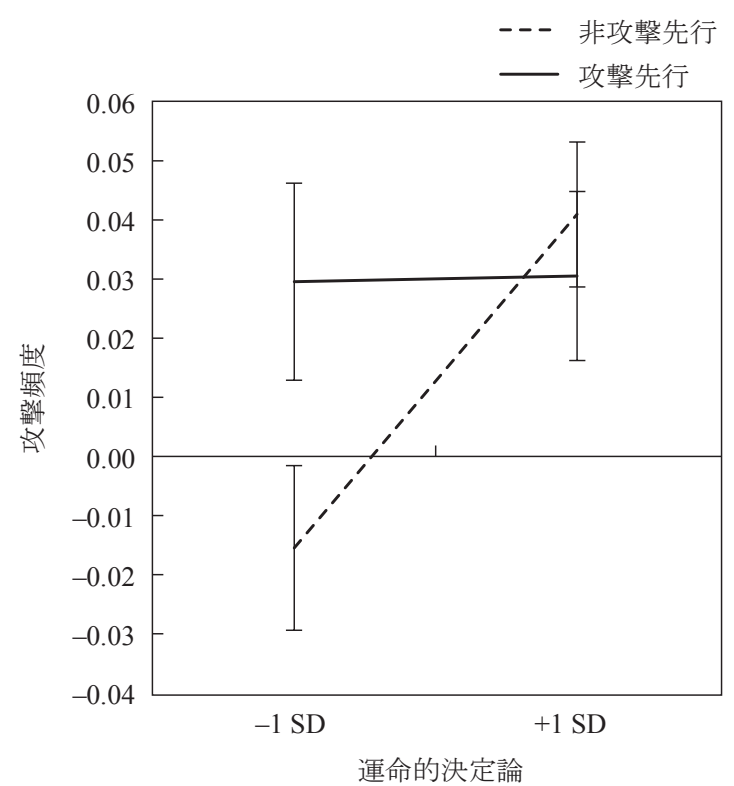

図 4 : 攻撃条件における運命的決定論と順序の交互作用効 果

交互作用（FD × 順序）について、攻撃先行では運命的 決定論への信念が強いほど攻撃頻度が増える効果が有意 で、非攻撃先行では運命的決定論への信念が強いほど攻 撃頻度が減る効果が有意であった（攻撃先行 : $\beta=.700, p$ $=.014$; 非攻撃先行 : $\beta=-.525, p=.012$; 図 5)。また、運 命的決定論と攻撃特性の交互作用（FD $\times \mathrm{BAQ})$ について、 攻撃特性が高い群において、運命的決定論の有意な正の 効果が見られた（ $\beta=.396, p=.025$; 図 6)。

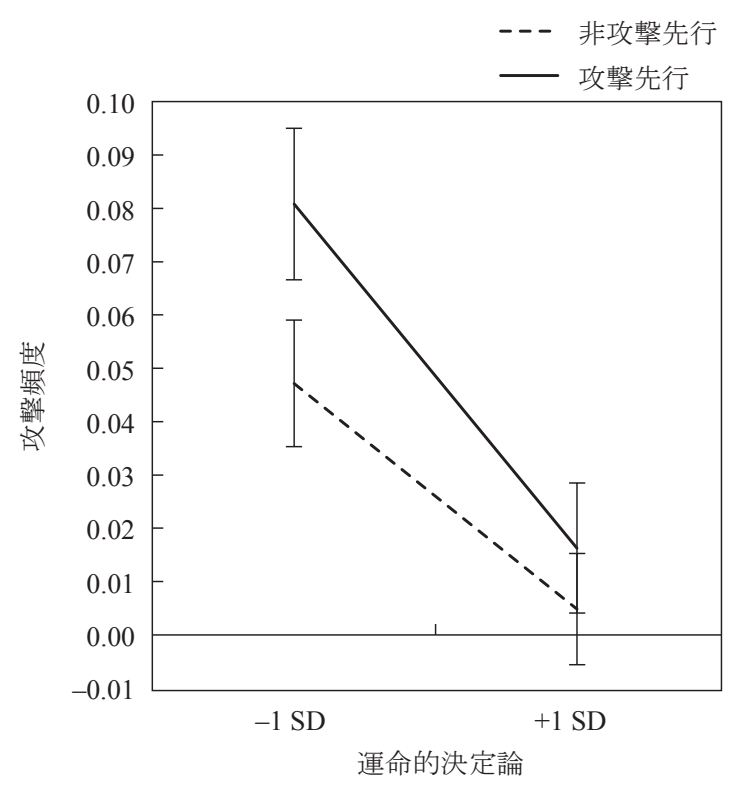

図 5: 非攻撃条件における運命的決定論と順序の交互作用 効果

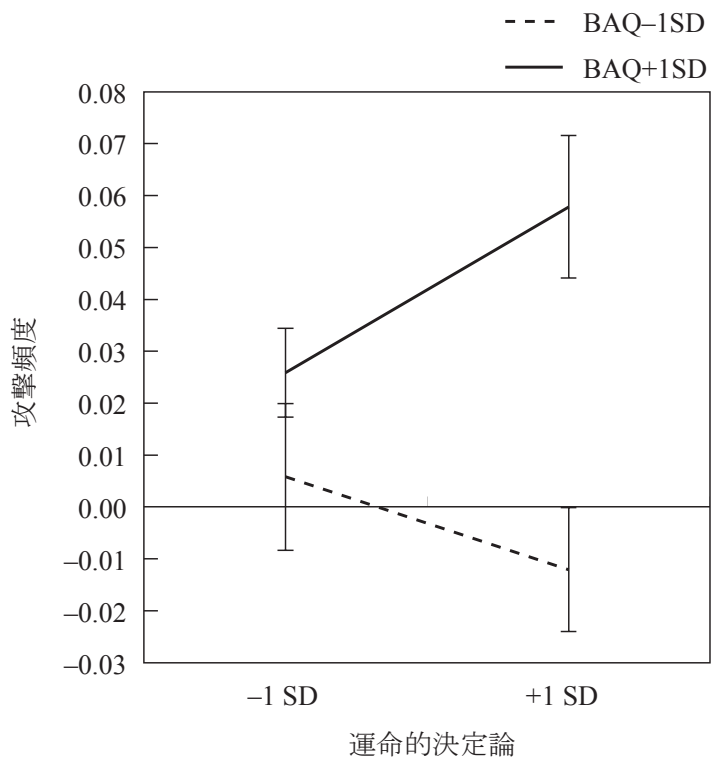

図 6: 非攻撃条件における運命的決定論と攻撃特性の交互 作用効果

\section{4. 考察}

本研究では、松本ら（2014）の研究を踏襲し、自由意 志信念と社会的相互作用場面での攻撃行動の関連につい て検討した。仮説は「自由意志信念が高いほど、攻撃的 な他者に対する攻撃行動が増加する」というものであっ た。

実験結果は、自由意志信念と攻撃行動の間の明確な関 連を示すものではなかったが、自由意志と関連する尺度 である運命的決定論については、攻撃頻度に対して影響 を与えることが示唆された。攻撃先行に関して、攻撃条 件では、運命的決定論的傾向による攻撃頻度の変化はな 
く、一貫して本実験の参加者全体の攻撃頻度の平均值で ある 0.026 と同程度の值（以下、基準值と呼ぶ）をとった。 一方、非攻撃条件では、運命的決定論的傾向が強い参加 者の攻撃頻度は基準值と同等であったが、運命的決定論 的傾向の弱い参加者の攻撃頻度は基準值よりも低かった のである。

このような結果は、自分の行動に対する責任という観 点から考察することが出来るだろう。まず、攻撃を受け ていない場合の攻撃行動では、その攻撃行動の原因を相 手からの攻撃に帰属することができないため、自分に責 任を感じやすくなると考えられる。さらに、運命的決定 論的傾向が弱いと、自分の攻撃行動が運命として決まっ ているものではないと考えるため、より責任を持つよう になる。その結果、非攻撃条件では運命的決定論的傾向 が弱いほど攻撃頻度が低くなった、と考えることができ る。一方、非攻撃先行非攻撃条件では、運命的決定論的 傾向が弱い参加者の攻撃頻度が基準值程度であったのに 対し、運命的決定論的傾向が強い参加者では攻撃頻度は 基準值より低かった。これに関しても、先述の、運命的 決定論が責任感につながり攻撃頻度が減るという解釈が 可能である。なお、攻撃条件では、非攻撃条件と傾向は 同じだが全体的にグラフを平行移動させたような結果に なった。これは、単純に攻撃を受けたことによって応報 的な攻撃をする動機が促進されたためであると考えられ る。また、初めに非攻撃条件を経験したことによって、 それと比較して攻撃条件の攻撃の効果がより強く感じら れた可能性もある。

ただし、本研究には手続き上の課題が存在する。PSAP 課題の実行に際し、ボタンをプッシュするのに必要な時 間が想定より短く、3 を押してペアからの攻撃を防御して いる 10 秒間に 1 を 50 回押すことができたため、攻撃を 一切受けずに得点することが可能であった。それによっ て、参加者間で攻撃条件の効果にばらつきが大きくなり、 実験操作の効果が検出しにくくなった可能性もある。参 加者が防御している間にも、攻撃を受けたことがわかる ような工夫が、今後、この課題を用いた研究では必要と なるだろう。

以上の限界はあるが、本研究では運命的決定論が自己 の行為への責任の感じ方に影響を与え、それによって攻 撃行動が変化するという可能性が示唆された。自由意志 信念は、私たちの自己制御行動を支える基盤となる可能 性は、他の多くの研究が論じているとおりであり、報復 としての攻撃もまた、その検討対象となる重要なテーマ である。本研究が示唆した運命的決定論と攻撃行動との 間の媒介変数についてはさらに入念な検討が必要であり、 他の自由意志信念の下位次元や統制感や責任帰属など、 関連する変数との関係も踏まえつつ、研究を進めていく ことが求められる。

\section{謝辞}

本研究は日本学術振興会科学研究費 (16H03726; 研究代 表者・唐沢かおり）の助成を受けた。

\section{引用文献}

安藤明人 - 曾我 祥子 - 山崎勝之 - 島井哲志 - 嶋田 洋徳 宇津木 成介 ・ 大芦 治・坂井 明子. (1999). 日本版 BussPerry 攻撃性質問紙 (BAQ) の作成と妥当性, 信頼性の検 討. 心理学研究, 70(5), 384-392.

Baumeister, R. F., Masicampo, E. J., \& DeWell, C. N. (2009). Prosocial benefits of feelingfree: Disbelief in free will increase aggression and reduces helpfulness. Personality and Social Psychology Bulletin, 35(2), 260-268.

Brewer, L. E. (2011). Forging freely: Perceptions of moral responsibility mediate the relationship between belief in free will and willingness to forgive. Electric Theses, Treatises and Dissertations.

Carré, J. M., Gilchrist, J. D., Morrissey, M. D., \& McCormick, C. M. (2010). Motivational and situational factors and the relationship between testosterone dynamics and human aggression during competition. Biological Psychology, 84(2), 346-353.

Cherek, D. R., Moeller, F. G., Schnapp, W., \& Dougherty, D. M. (1997). Studies of violent and nonviolent male parolees: I. Laboratory and psychometric measurements of aggression. Biological psychiatry, 41(5), 514-522.

鎌原 雅彦・樋口一辰・清水直治. (1982). Locus of Control 尺度の作成之, 信頼性, 妥当性の検討. 教育心理学研究, 30(4), 302-307.

Lipkus, I. (1991). The construction and preliminary validation of a global belief in a just world scale and the exploratory analysis of the multidimensional belief in a just world scale. Personality and Individual Differences, 12(11), 1171-1178.

松本 龍児・桜井良祐 ・渡辺 匠・唐沢 かおり.(2014). 自由 意志信念が対人相互作用場面での攻撃行動に与える影 響. 人間環境学研究, 12(2), 113-117.

大㴊 憲一. (1987). 攻撃の動機と対人機能. 心理学研究 58(2), 113-124.

佐藤徳 \& 安田朝子. (2001). 日本語版 PANAS の作成. 性 格心理学研究, 9(2), 138-139.

Schooler, J., Nadelhoffer, T., Nahmias, E., \& Vohs, K.,D. (2014). Measuring and manipulating beliefs and behaviors associated with free will. Surrounding free will: Philosophy, psychology, neuroscience, New York, Oxford University Press. 7294.

白井 美穂 . (2010). 㛜罰傾向と公正世界観の理解へ向けて (2) 尺度の検討. 東洋大学大学院紀要 47, 151-166.

Taylor, S. P. (1967). Aggressive behavior and physiological arousal as a function of provocation and the tendency to inhibit aggression. Journal of personality, 35(2), 297-310.

Vohs, K. D., \& Schooler, J. W. (2008). The value of believing in free will: Encouraging a belief in determinism increases cheating. Psychological Science, 19(1), 49-54.

渡辺匠・櫻井良祐・綿村英一郎・唐沢かおり. (2014). 自由意志 - 決定論尺度（The Free Will and Determinism 
Plus Scale : FAD +) 日本語版の作成. パーソナリティ

研究, 23(1), 53-56.

（受稿：2017 年 5 月 18 日 受理：2017年 6 月 7 日） 